\title{
TARIHI DOKUDA KENTSEL MÜDAHALE BiçiMi OLARAK KAMUSAL SANAT: AMASYA ÖRNEĞi*
}

\author{
PUBLIC ART AS A FORM OF URBAN INTERVENTION IN HISTORICAL URBAN FABRIC: \\ THE CASE OF AMASYA
}

\author{
Pınar Çalışır Adem ${ }^{* *}$, Bige Şimşek İlhan ${ }^{* * *}$, Deniz Özge Aytaç ${ }^{* * * *}$, Emel Birer $^{* * * * *}$
}

\section{Öz}

Sanatı, kent yaşamı ile bütünleştirmenin yollarından biri; sanatı, kentlinin günlük yaşamında kolaylıkla erişebileceği kamusal mekânlara taşımaktır. Bu yöntemle; hem sanat eseri varlığını ortaya koyarak kentliye ulaşacak hem de kentli sanat etkinliğinin fiziksel, sosyal ve kültürel yapısından faydalanma fırsatı bulacaktır. Bu makale, tarihi kentlerde, kent dokusuna ait artifaktların sanatsal bir ifade ile yorumlanarak kamusal mekânda nasıl sanat eserlerine dönüştürülebileceğini ve bu yol ile kentliler için karşılaşma mekânları oluşturularak, kentsel mikro müdahalelerin kamusal sanat aracılığı ile nasıl gerçekleştirilebileceğini, "Kentsel Mekâna Müdahaleler: Özgün Mahalle Dokusunda Karşılaşma Mekânları" isimli çalıştayın sonuçları üzerinden tartışmaktadır. Kamusal mekânlar, kamusal sanatın temsil yeri olurken, aynı zamanda kentlilerin karşılaştığı ve diyaloğa girdiği, kamusal iletişimin yaşandığı yerlere dönüşme potansiyeli taşır. Bu anlamda, tarihi kent içindeki kamusal mekânlarda, mikro ölçekli kentsel müdahalelerin sanat içerikli olması, tarihi mekânın kimliğini korumaya, kent imajını güçlendirmeye, gündelik hayat ve kentin mevcut problemlerine sürdürülebilir çözüm önerileri bulmaya yardımcı olabilir.

Anahtar Kelimeler: Kamusal Mekân, Kamusal Sanat, Kentsel Müdahale, Amasya.

\section{Abstract}

One way to integrate art into urban life is to convey the art into public spaces in which the city dweller is able to access easily in his daily life. In this respect, the art work will reach the city dweller through revealing its essence, as well as the city dweller will benefit from the pyhsical, social and cultural structure of the art activity. This article discusses how artifacts of urban fabric in historic cities can be interpreted with an artistic expression and transformed into art works in the public space, so that they can create spaces of encounter for the city dwellers and be realized as micro-scale urban interventions by the public art through results of the workshop named "Interventions to Urban Space: Encounter Spaces in Traditional/Unique Neighbourhood". As public spaces are performance spaces of the public art, they have a potential to transform into places where the city dwellers encounter and engage in a dialog, and public interaction occurs at the same time. In this context, if micro-scale urban interventions

Araştırma Makalesi // Başvuru tarihi: 16.03.2019 - Kabul tarihi: 30.06.2019.

*Bu çalışma, Amasya Üniversitesi'nde 2017 yılında gerçekleştirilen “Kentsel Mekâna Müdahaleler: Özgün Mahalle Dokusunda Karşılaşma Mekânları" isimli çalıştayın sonuçları üzerine oluşturulmuştur.

** Öğr. Gör., Yeditepe Üniversitesi, Mimarlık Fakültesi, Mimarlık Bölümü, pinarrcalisir@gmail.com, https://orcid.org/0000-0001-6139-6289.

${ }^{* * *}$ Dr. Öğr. Üyesi, Amasya Üniversitesi, Mimarlık Fakültesi, Kentsel Tasarım ve Peyzaj Mimarlı̆̆ı Bölümü, bigesimsek@gmail.com. https://orcid.org/0000-0002-5169-153X.

****Araş.Gör., Amasya Üniversitesi, Mimarlık Fakültesi, İç Mimarlık Bölümü, ozge.aytac@amasya.edu.tr, https://orcid.org/0000-0002-8144-3983.

${ }^{* * * * *}$ Doç. Dr., İstanbul Kültür Üniversitesi, Mimarlık Fakültesi, Mimarlık Bölümü, e.duzgunbirer@iku.edu.tr, https://orcid.org/0000-0003-0152-3690. 
have art context, public spaces within historical urban context can benefit from conserving the historical space's identity, enhancing image of the city, finding sustainable solutions to daily life and existing issues of the city.

Keywords: Public Space, Public Art, Urban Intervention, Amasya.

\section{Giriş}

Müdahale (interfere, intervention; cut in, step in, treat) sözlük anlamı ile karışma, araya girme ya da el atma anlamlarıyla dilde yer alır. Bu anlamı ile bakıldığında kentsel mekâna müdahale, mevcut durumu koruyarak kentsel mekâna karışmak, bulunduğu ortama girmek ya da bir şekilde el atmak olarak gerçekleştiğinde, mekânın sürdürülebilir niteliği ortaya konulmuş olur. Özellikle tarihi kentlerde yapılacak kentsel müdahalelerde kullanılacak yöntem, kentin tarihi mirasının sürdürülebilirliği adına önemlidir. 1960’lı yıllardan sonra hızla gelişen endüstrileşme ve günümüzde hızlı kentleşme süreçleri sonucunda, şehirlerin tarihi süreçte evrilen ekonomik, toplumsal, biçimsel, sosyal ve kültürel bütünlükleri ve bu bütünlüğün sonucu oluşan özgün kimlikleri kaybolmaya başlamıştır (Özer, 1986). Bu süreçte "kentler kendi kültürel simgelerini yaratmamak gibi bir yozlaşma" içindedir (Özer, 1986:47). Tarihi kentlerde yapılacak müdahalelerin mevcut dokuya zarar vermeden, sanat yoluyla, kamusal mekânlarda gerçekleştirilmesi ve sanat eserlerinin, tarihsel morfolojiye göndermeler yapılarak tasarlanması, tarihi çevre imajı ve kent kimliğinim güçlendirilmesine ve kente ait kültürel simgelerin oluşturulmasına yardımcı olacaktır. Aynı zamanda, bu mikro ölçekli kentsel müdahaleler, kamusal mekânlarda gündelik yaşamın bir parçası halinde var olarak sosyal yaşantıya da katkı sağlayacaktır.

Kentin önemli işlevlerinden biri, öncelikle kendi tarihsel sürecimize ışık tutmasıdır. Tarihi kentler bize, geçmişte, geriye uzandığımızı hissettirirken; yeni yapılaşmalar ve uygulamalar, bizi geleceğe ve beklentilerimize yönlendirecektir. Bu açıdan kentte, çağdaş sanat ve mimarlık uygulamaları ile karşılaşmak, kendimizi yaşanılan zamana ait hissetmemiz için önemlidir (Erzen, 2015). Kentin diğer önemli işlevi, sosyal olanıdır (Erzen, 2015). Kentte insanlar, farklı kültürlerden insanlarla beraber yaşar ve ortak bir mirasa sahip olur. Eğer kamusal mekânlar sadece geçiş amaçıı değil, diyalog ve duraklama amacıyla da tasarlanabilirse, bu mekânlar, farklı kültür ve görüşten insanların birbiri ile temas ettiği, kendi çevresini aştığı, 
çok boyutlu ve daha interaktif bir insan olmasını sağlayacak karşılaşma mekânlarına dönüşebilir. Bir başka deyişle, kamusal mekânlar, kamusal sanatın temsil yeri olarak, kentlilere duraklama alanları yaratıp, kentliler arasında bir diyaloğa ve karşılaşma durumuna olanak sağlar.

Günümüzde, kentlerin sahip olduğu kültürel değerleri tanıtmak üzere, kamusal sanat projeleri gerçekleştirilebilmektedir. Yerel kimliğin ve yer imajının güçlendirilmesi amacıyla, kamusal sanat, yere özgü kavram ve nesnelerin sanat eserlerine dönüşmesi yoluyla ortaya çıkabilir. Bu bağlamda sanat, kente kültürel perspektiften müdahale eder ve mikro kentsel bir müdahale biçimine dönüşür (Mccarthy, 2006). Diğer bir deyişle, kamusal sanat, kentlerin kendi özgün kimliklerine öykünebilir ve geçmiş ile gelecek arasındaki ilişkiye ve sürekliliğe dayanarak, kültürel gelişimin bir parçası haline gelebilir. Bu ifade biçimi içinde sanatçı, geçmişe ait kopyalar üretmek ve direk alıntılar yapmak yerine; tarihsel sürecin farkında olarak geçmişi yorumlamalıdır (Özer, 1986).

Bu makaledeki çalışmanın amacı, tarihi kentlerde, kent dokusuna ait artifaktların sanatsal bir ifade ile yorumlanarak kamusal mekânda sanat eserlerine nasıl dönüştürülebileceği ve bu yol ile kentliler için karşılaşma mekânları oluşturularak tarihi kentte, kentsel mikro müdahalelerin kamusal sanat aracılığı ile nasıl gerçekleştirilebileceğini "Kentsel Mekâna Müdahaleler: Özgün Mahalle Dokusunda Karşılaşma Mekânları” isimli çalıştayın sonuçları üzerinden tartışmaktır.

\section{Tarihi Dokuda Mikro Kentsel Müdahale}

Tarihi kentler, oluşumu yüzyıllar boyunca sürmüş, farklı katmanlarında geçmiş uygarlıkların izlerini barındıran sit alanlarıdır (Tanaç Zeren, 2010). "Tarihi kentler bir bütündür" ve bütüne ait parçalar, tarihi alanı meydana getiren mahallelerin ve sokakların artifaktlarıdır (Tanaç Zeren, 2010:17). Tarihi çevrenin fiziksel dokusu yanında, bu çevreyi oluşturan bir diğer önemli faktör kentlilerin yaşantısıdır. Yaşam biçimi fiziksel doku ile beraber, tarihi kentlerin çevresel kimliğini belirler (Tanaç Zeren, 2010). Bu nedenle; kentsel mekâna müdahale, sadece fiziksel dokuya değil, aynı zamanda kent yaşamına da dokunur ve kamusal mekânların tasarlanmasından, birey ve toplum hayatının çok çeşitli boyutlarına kadar, doğrudan etki yapar. 
Kentsel mekâna "müdahale" kavramı, daha çok "sorunlu bir yerin mimari, tasarımsal programla dönüştürülmesi ve yenilenmesidir" (Tan, 2009:59). Tanımının doğası gereği, kentsel müdahaleler, kentsel problemlerin tespit edilmesi ile ortaya konulabilir. Kenti anlamaya çalışmak, kent ve kentliyi birbirinden ayrılmaz bir bütün olarak kavramak, gerçekte her birinin bireysel gereksinimleri farklı olan kentlilerin, kentsel eylem ve pratikleri için kentin tasarlanması gerektiğini anımsamak, kentsel müdahalelerin yapısını belirler. Jacobs'a göre (2011:443), kentler "yaşam bilimlerinde olduğu gibi örgütlü karmaşıklık" ortaya koyar. Kenti oluşturan bütün parçalar birbiri ile bir şekilde etkileşimde bulunur. Bunu göz ardı ederek, parçaları birbirinden kopararak gerçekleştirilen müdahaleler, yalıtılmış ve kent sisteminden koparılmış mekânların ortaya çıkmasına neden olur. Geleneksel modern şehir planlaması, kenti basit ve örgütsüz karmaşıklık problemleri olarak görüp (Jacobs, 2011), bölgeleme mantığıyla kente parçacı bir tutumla yaklaşarak, kenti kuş bakışı temsil eden haritalar üzerinden, kentsel makro müdahaleler gerçekleştirmeyi hedeflemiştir (Akgün Yüksekli, 2015).

Postmodernist dönemde; modernismin akılcı, bütüncül ve kapsamlı bakış açısına ters bir yaklaşımla, kentin parçalar halinde gelişmesi olgusu yaratılmıştır. Özellikle özel yararı ve kentsel rantı maksimize eden parçacı imar planı değişiklikleriyle mekân (yeniden) üretilmiştir (Keskinok, 1998; Eren, 2007; Ersoy, 2007). Eren'e (2007) göre, parçacı söz konusu müdahaleler sermayedarın istemi doğrultusunda yapılmaktadır. İmar planı değişiklikleri modernism ilke ve esaslarını barındıran mekânsal planların bütünlüğünü bozmuş ve plan kararlarına aykırı kentsel parçalar yaratılmasına izin vermiştir.

Günümüzde, kentin parçalar halinde algılanması; kamu yararına aykırı ve bazı durumlarda kamu alanını veya mekânını ve dolayısıyla kentin kimliğini yok edici nitelik kazanmıştır (Eren, 2009). Dahası, kentte kamusal mekânlar yaratmak amacı ile kamusal işlevlerin kent çeperlerine taşınması, kentin gelişim süreci sonucu oluşan toplumsal ve mekânsal bağlamlarını yitirmesine ve tarihsel merkezlerin anlamlarını kaybetmesine olmuştur (Keskinok, 2012). Kent dokusu içerisinde, kent dokusundan, fiziksel ve sosyal anlamda kopuk, fakat kendi içerisinde bütünlüğü olan yerleşim alanları yaratmak ise; içeride nitelikli yaşam alanları oluşturulsa dahi, kent bütünlüğünü ve kamusal mekânlardaki birliği olumsuz etkilemektedir (Keskinok, 2012). Bu örneklerden anlaşılacağı gibi, makro ölçekli müdahaleler 
kentlinin gündelik sorunlarından uzakta, kenti parçalara ayıran bir bakış açısı içerisinde meydana gelme riski taşır. Oysa tarihi doku, tam da kent içinde, parçacılıktan uzak, kentin bütünü ile düşünülmesi gereken müdahalelere sahne olmalıdır.

Büyük ölçekli makro müdahalelere karşı, geçici mikro mekânsal müdahaleler, değişik zaman ya da mekân ilişkileriyle var olan mekânsal sistemin içine girip, etkilemek ya da var olan şartları değiştirmek anlamına gelir (Tan, 2009:59). Bu bağlamda kente, kentsel planlama ölçeğinden daha küçük ölçeklerde, mikro müdahale etme fikri, 1950'li yıllardan itibaren kentliyi merkeze alan, insancıl bir sosyal ve fiziksel çevre yaratmaya yönelik ihtiyaçlara odaklanan bir anlayış sonucu gündeme gelmiştir (Akgün Yüksekli, 2015). Uzer'e göre (2013), kamusal alanda küçük ölçekli mikro müdahaleler, basit teknolojileri kullanan, kentlileri sürece dahil edebilen, dönüştürülmeye açık, esnek, kamusal mekana katkısı yüksek, tasarım araçları olarak görülebilir.

Tarihi dokuda yapılacak geçici, ekonomik ve tekrar edilebilir mikro müdahaleler, konsept tasarımlardan çok, gündelik hayata yönelik olmaları açısından kentsel tasarım projelerinden farklılaşır. Bu nedenle; kentsel mikro müdahalelerin bir bölümü, kentsel tasarım projelerinde kullanılan konsept, yaklaşım ve tasarım yöntemlerine dönüştürülemez bir strüktüre sahiptir. Kamusal sanat, tam da bu noktada tarihi kente yapılacak mikro müdahalelere zemin hazırlar ve yaratıcı metotları tasarımcıya bırakır.

\section{Kamusal Mekân, Kamusal Sanat}

Kamusal mekân, bir kentte yaşayan insanların fiziksel çevre ve birbirleriyle karşılıklı diyalog ve ilişki kurarak beraber kullandıkları alanlardır. Bu özelliği ile kamusal mekânlar, "toplumsallaşma ve sosyalleşme" araçlarıdır (Gökgür, 2008:17). Kentliler serbestçe girebildikleri bu alanlarda beraber olmak, birbirine selam vermek, özür dilemek, fikirlerini paylaşmak, bilgi almak gibi sosyalleşmelerini sağlayan ve topluluk bilincini güçlendiren eylemlerde bulunurlar (Gökgür, 2008). Kamusal mekânlar, bu eylemler ile birlikte karşılaşma mekânlarına dönüşerek, kentlilerin diyalog kurdukları duraklama mekânlarını yaratırlar. Kentin sokakları, parkları, meydanları kentlilerin etkileşimini yönlendirir. Kamusal mekânlar aynı zamanda kent kimliğinin de taşıyıcısıdır. Bir kamusal mekân, sadece geçiş eylemi için tasarlanırken; diğeri, farklı ve birden fazla işlevi içerebilir (Gökgür, 2008). 
Habermas (1997), kamusal mekân kavramı yerine kamusal alan (public sphere) kavramını kullanarak, onu her şeyden önce kamuoyunun içinde oluştuğu, özgür bir politikanın ve onun varlığından oluşan kültürün oluşturduğu her türlü alan olarak tanımlamaktadır. Bu anlamı ile kamusal alan sembolik ve daha kapsayıcı bir kavram olup, bir fiziki çevreyi tanımlayan kamusal mekân olgusunu da içine almaktadır. Bu anlamda kentlinin yaşadığı yerden dışarıya çıkması, kamusal mekâna çıkmasıdır. Yürümek, başkalarıyla karşılaşmak, buluşmak, konuşmak, tartışmak, dayanışma ve eylem imkânı veren ortak mekânlar, kent içinde kamusal mekânlar; bir başka deyişle karşılaşma mekânlarıdır. Kentteki çok farklı açık ve kapalı kamusal mekânlar; mahallelerle ve tarihi doku ile çevrili ortak alanlar, yürüyüş alanları, pasajlar, çarşı-pazar, halkın kullanımına açık deniz kıyıları, sokaklar ve çocuk oyun alanları, kültür ve sanat gösterisi yapılan yerler, miting alanları, kafe ve kulüpler olarak sıralanabilir (Özbek, 2004).

Anadolu'daki tarihi kentlerde, kamusal mekân kavramı bugün hala sorgulanmaktadır. Özellikle Anadolu kentlerinde tarihi süreçte, konutlarda ev önleri, mahallelerde cami bahçeleri, mahalle kahveleri, çeşme önleri kamusal mekânlar olarak sıralanabilir. Tanyeli (2006), bugün hala kamusal mekânın tanımlanamamasını, onun, Osmanlı ve İslam kaynaklarında bulunmamasına bağlamaktadır. Kamusal mekânın Osmanlı kaynaklarında 19. yüzyılda Batı'daki "public" kelimesinin kökeninden başka bir anlamda yer aldığını ve kamusal mekânın genelde devlete ait bir kelime olarak kullanıldığını belirtir. Kamusal mekân "public"e ait olan değil, otorite ile etkileşimin sağlandığı mekândır. Özellikle tarihi dokuda halen, cami bahçeleri, mahalle kahveleri, çeşme önleri kamusal mekânlar olarak var olmaktadır.

Kamusal sanat kavramı genel olarak, bir sanat yapıtının basitçe bir kamusal mekâna yerleştirilmesini gerektirmektedir (Sheikh, 2007). Sosyolojik açıdan bakıldığında, kamusal mekânda gerçekleştirilen sanatın edindiği amaç, kentsel mekân içerisinde yer alan objeleri ve olguları estetik olarak harekete geçirerek bir düşünce yaratma pratiğidir (Remesar, 2001). Kamusal mekâna yerleştirilen eserlerden, özel alandaki sanattan (müze ve galeriler arasında alınıp satılan, dolaşıma giren) izleyici ve kent ile kurduğu ilişkilerin nitelikleri açısından ayrışması beklenir (Sheikh, 2007). Bu nedenle, kamusal sanat, gündelik hayatın bir parçası olarak (Mitchell, 1992), kullanıcıları da içine almak üzere, mekânı oluşturan tüm elemanlarla etkileşime giren sanattır. 


\section{SDÜ ART-E}

Güzel Sanatlar Fakültesi Sanat Dergisi

Günümüzde yaygınlaşan eğilimlerden biri, sanatı bireysel eylemlerden, daha genel siyasi söylemlere varana kadar, yaşamın her türlü alanıyla bütünleştirmeye çalışmaktır. (Shiner, 2004). Kamusal sanat, kentliyi sadece izleyici olmaktan çıkaran, katılımcıya da dönüştürebilen, gündelik hayatın içine girerek, sosyolojik problemlere değinen, farkındalık yaratan, süreç odaklı bir sanat türü haline gelmiştir. Kamusal sanat eserlerinin birçoğu artık, yere bağlılı̆̆ öne çıkarmak, değişik kültür ve tarihlere sahip çıkmak, sanatı kentlinin ayağına getirmek, izleyici/katılımcı, sanat/sanatçı arasındaki mesafeyi azaltmak, siyasi duruşlara yer vermek, kurulu/yerleşik sosyal sisteme tepki göstermek, farkındalık yaratmak, iletişim kurmak, karşıt görüşlerle müzakere yapabilmek ve olumlu bir amaca yönlendirmek, demokratik, eşitlikçi kamusallıklar yaratmak gibi özellikler ile varlı̆ı̆ı ortaya koymaktadır. Sanat, kamusal mekânın içinde alternatif alanlar üretilmesine yardımcı olur; farklı bir ifadeyle, sanat, kamusal mekânın farklı imkânlara da açık olduğunu ima etmektedir (Tan, Boynik, 2007). Sanat üzerinden oluşturulacak bu alternatif mekânlar, tarihi dokuda, kentsel bir mikro müdahale biçimi olarak başladığında, kamusal sanatın tüm kente yayılma potansiyelini güçlendirecektir. Sanatın bu kadar farklı işlevlerle kentliyle temas edebilmesi, kamusal sanatın değişik biçimlerde ortaya çıkmasını sağlamıştır.

\section{Kamusal Mekânda Sanatın Ortaya Çıkış Biçimleri}

Sanatın doğasında var olan zengin değerler ve sanatçının sınırları zorlar tavırları, kamusal mekânlarda sanatın ortaya çıkış biçimlerine zemin hazırlar. Kamusal mekânlara sanat objelerinin yerleştirilmesinde önemli olan faktör, sanat eserinin yerleştirileceği mekânla ilişkisi ve o mekânda sanat eseri ile kentlilerin iyi bir diyalog kurabilmesinin sağlanmasıdır. İnsan ölçeği; sanat eseri ve kentli arasında iyi bir ilişki sağlanabilmesi için ihtiyaç duyulan temel noktalardan biridir.

Kentlerin sahip oldukları kültürel değerleri tanıtmak üzere kamusal sanat projeleri gerçekleşebilmektedir. Yerel kimliğin ve yer imajının güçlendirilmesi amacıyla kamusal sanat nesneleri kullanılabilir (Özer, 1986). Bu anlamda sanat, aslında tarihi kente kültürel perspektiften müdahale eden bir araca dönüşür (Mccarthy, 2006). Genellikle sanat eserleri kamusal mekânlarda "yerleştirme, duvar-zemin boyama ve yüzey oluşturma, kamusal mekân sergileri, kentsel mobilyalar ve izleyici etkileşimli sanat olayları" şeklinde yapılmaktadır. Bazen 
de sanatın ön görülemez yaratıcı potansiyeli "kamusal mekânlarda sanata yönelik değişik yaklaşımları" barındııı (Bayram, 2007).

Yerleştirme: Birçok kentte bugün kamusal sanatın en sık rastlanan örneği, kentteki konumuna bağlı seçilen binalar ya da plazalar önüne yerleştirilen modernist ve soyut heykel çalışmalarıdır (Oktay, 2003). Modern kentin, modern anlayışına uygun yapılaşan sergi anlayışı, bu düşünceyle benzerlikler barındırır. Oysaki tarihi dokuda yapılacak yerleştirme çalışmalarında, sergi nesnesinin kendisinin de sergi nesnesi olan tarihi dokuda yer aldığı unutulmamalıdır. Kentliler, tarihi dokuda sanatla karşılaştıklarında, yerleştirilen alan sanat eseri ile bütünleşerek tarihi doku ile birlikte kendini ortaya koyar. Açık hava müzesi olarak nitelendirilen Havana'da yerleştirilen heykel örneği, arkadaki tarihi fonu özellikle öne çıkaran boşlukları içerir (Görsel 1), Barselona'daki Frank Gehry'nin Altın Balık çalışması ise, tarihi dokuyu, arkada siluet oluşturacak şekilde kullanarak, çevreyle karşıt bir tutum ortaya koymaktadır. (Görsel 2). Bazı durumlarda kamusal sanat eseri tarihi dokunun üzerine yerleştirilerek onunla bütünleşebilir (Görsel 3). Kamusal sanat objesi bir yerleştirme olarak tarihi kentin meydanlarında ya da toplanma alanlarında yer alarak kentliler için bir geçit oluşturabilir (Görsel 4-5).

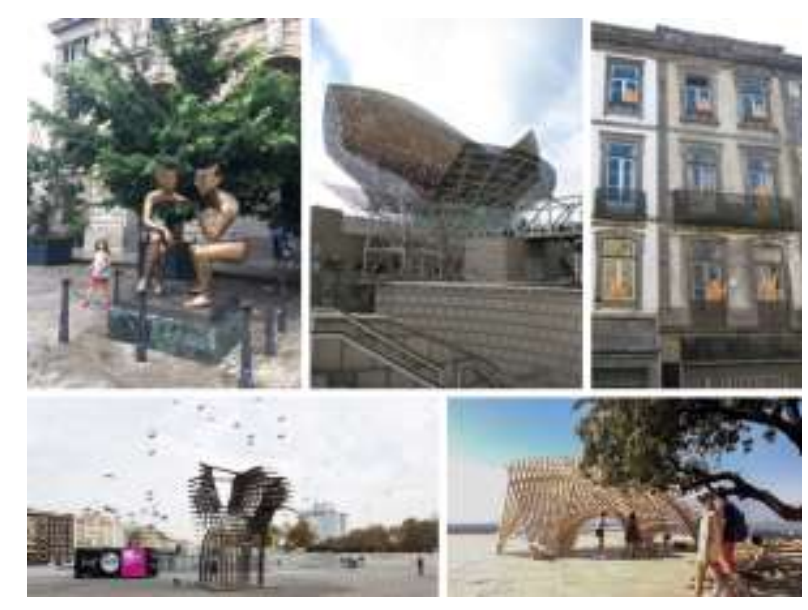

Görsel 1. Üst Solda. Küba Havana'da Tarihi Dokuda Yerleştirme (yazar arşivi). Görsel 2. Üst Ortada. Frank Gehry, Altın Balık Heykeli/El Peix, Barselona (yazar arşivi). Görsel 3. Üst Sağda. Porto'da Tarihi Kentte Bina Cephesinde Yerleştirme (yazar arşivi). Görsel 4. Alt Solda. GAD Architecture, Serra Gate, İstanbul, Taksim Meydanı. Görsel 5. Alt Sağda. So? Mimarlık, Mediterranean Triangle, Antalya.

Duvar-Zemin Boyama ve Yüzey Oluşturma: Yapıların sağır duvar yüzeylerini ya da tamamını renklendirme eğilimi, mimari elemanları görsel bir arayışüzerinden eğlenceli ve özgür nesneler haline getirmektedir. Bir caddenin ya da yüksek bir yapının cephesinde yüzey yaratma 
çabası, resim ve kabartma kullanılması, serbest plastik etkiler yaratarak, o mekâna farklı anlamlar kazandırmaktadır (Görsel 6-8). Kent algısını tamamıyla etkileyen renk, bugünün sanatındaki cesur değişimlerden biri olarak, çok sayıda mimari çalışmada da yer almaktadır. Doğa içindeki mekân dâhil, bir yerleşmenin yeniden yüzey oluşturma çalışmaları o alanın ayrıca marka değerini artırmaktadır. Küba'da Leovigildo Gonzalez Morillo'nun Vinales'de bir dağın üzerine resmettiği Mural de Prehistoria çalışması tarihi doğal sit alanında yapılmış bir çalışmadır (Görsel 7). Kamusal sanat tarihi dokuda anonim grafitiler olarak ortaya çıkabilir (Görsel 10), ya da dijital teknolojilerin yardımıyla bir bina cephesini baştan yaratabilir (Görsel 9).
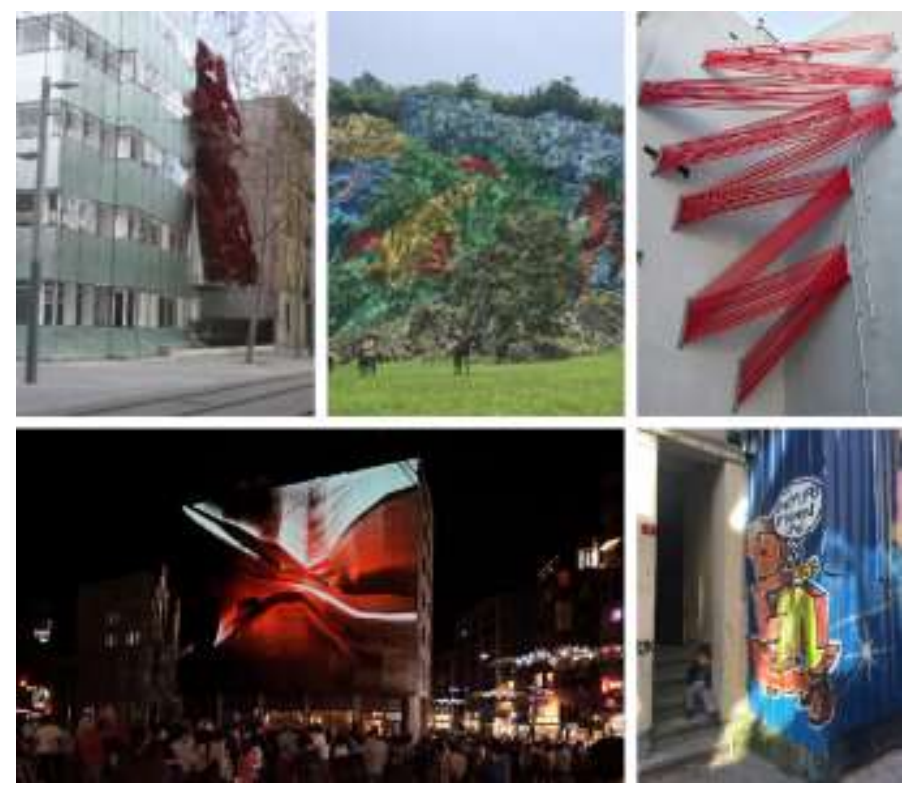

Görsel 6. Üst Solda. Barselona'da Bina Cephesinde Yüzey Oluşturma (yazar arşivi).

Görsel 7. Üst Ortada. Leovigildo Gonzalez Morillo, Mural de Prehistoria, Küba Vinales (yazar arşivi). Görsel 8. Üst Sağda. So? Mimarlık, Pray For Rain, Karaköy. Görsel 9. Alt Solda. Salon Architects, Augmented Structures V1.1, İstiklal Caddesi, İstanbul. Görsel 10. Alt Sağda. Grafiti Örneği, Balat (yazar arşivi).

Kamusal Alan Sergileri: Sanatçıların kendi sanatlarını kentin daha geniş çevrelerine iletmek ve kentli ile buluşturmak üzere yaptıkları sergiler kamusal mekânlarda yer alabilmektedir. Katılım ve karşıııklı etkileşim, bugünün sanatının ortaya çıkarılma nedenidir. İzleyiciler ile temas ve diyalog kurma, sanatçılar tarafından çeşitli şekillerde sunulmaktadır (Ögel, 1997). Bugün sanatçıların bireysel çabalarıyla kentlilerin, kamusal mekânlarda sayıları gittikçe artan kültürel faaliyetlerle daha sık karşılaşması ve kamusal sanatın, daha geniş bir kesimle buluşarak, kentin çağdaş vizyonunun öne çıkartılması, tanınırlı̆ııın artması 
amaçlanmaktadır. Bu çalışmalarda, sanat eseri, tarihi dokuyu bir fon olarak kullanarak tasarlanabilir. Tarihi dokuda var olan "burada olma" durumuna aykırı sergiler, kentliye çekim alanları da yaratır. Örneğin, Bounes Aires'de yer alan La Boca Bölgesi'ndeki çalışma, tarihi dokuyu renk renk bir kamusal sergi alanına dönüştürmektedir. (Görsel 11); ya da, (Görsel 12)'de olduğu gibi, sanatçı var olan bir manzarayı kendi sanat eseri yardımıyla işleyerek mekânla kurduğu ilişkiyi güçlendirmekte ve mekânı bir çekim noktasına çevirmektedir (Görsel 12). Tarihi dokuda belirli konulara dikkat çekmek ve farkındalık yaratmak amacıyla, duvar resimlerinin kalıcı olarak sergilenmesi (Görsel 13) ya da duvar yüzeyinde sergilenebilen küçük boyutlu heykel çalışmaları (Görsel 14)'da; kamusal mekânda sanatsal sergiler yoluyla cazibe noktaları yaratabilmektedir.

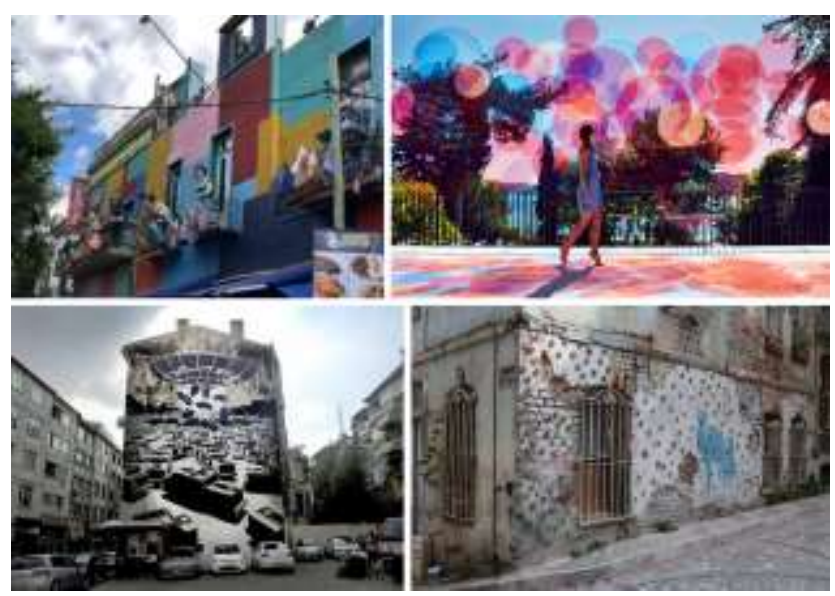

Görsel 11. Üst Solda. Bounes Aires La Boca'da Tarihi Doku Üzerinde Kişisel Heykel Sergisi (yazar arşivi). Görsel 12. Üst Sağda. Paul Cocksedge Studio, Palette, İstanbul. Görsel 13. Alt Solda. Muralist Örneği, Yel değirmeni, Kadıköy. Görsel 14. Alt Sağda. Eda Soylu, Duvar Kâğıdı, Balat.

Kent Mobilyaları: Kentsel mekânlarda kent mobilyaları, yaşam kalitesini artırır ve mekânın kalitesine katkı sağlar. Buna ek olarak sanat objeleri olma çabaları şeklinde, çeşitli yaklaşımlar da mevcuttur (Şenliyer, 1995). Kent mobilyaları, otobüs durakları, oturma elemanları, özelleştirilmiş zemin döşemeleri, bisiklet parkurları ve parkları, tabelalar, kiosklar, aydınlatma elemanları gibi kamusal mekânlarda olan çeşitli işlevsel elemanlar sanat eseri olarak ele alındığında kentlinin farkındalık düzeyi de artmaktadır. Kent mobilyalarının fonksiyonel değerlerinin yanında o alana özgü sanatsal değerlerinin de bulunması gündelik yaşamda kentliyi kente bağlayan nedenler olarak arzulanır. Tarihi dokuda yer alacak kent mobilyaları, zaman 
algısındaki değişimi bazen renkleri ile bazen de kentliyi şaşırtacak yeni biçimleri ile kentsel mekânlarda ortaya koyar (Görsel 15-16). Kent mobilyaları mimari ölçekte bir yerleştirmenin parçası olarak kamusal mekânda kentliler ile buluşabilir (Görsel 17-18).

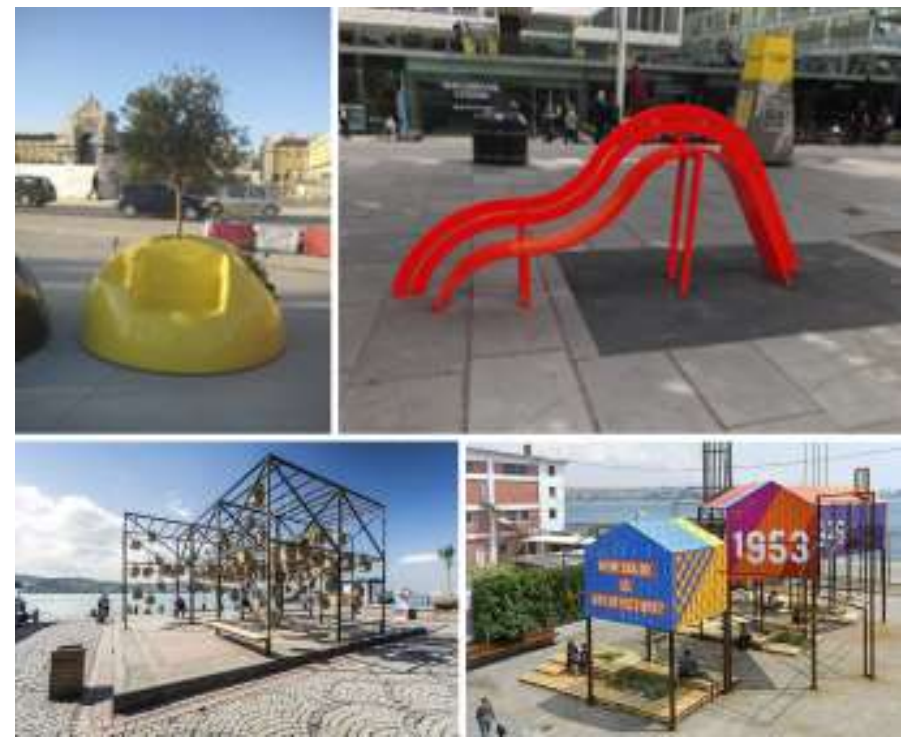

Görsel 15. Üst Solda. Lizbon'da Kent Mobilyası(yazar arşivi). Görsel 16. Üst Sağda. Londra'da Kent Mobilyası(yazar arşivi). Görsel 17. Alt Solda. So? Mimarlık, Sky Garden, Beşiktaş. Görsel 18. Alt Sağda. Pattu Mimarlık, Katı Olan Her Şey, Karaköy.

İzleyiciyle Etkileşimli Sanat: Günümüzde sanat nesnesini veya sanatın artık bir süreç olarak görülmesini tartışmak kadar, nesne ve mekân ilişkisini tartışmak da çok önemlidir. Nesne ve mekân ilişkisinin bir başka yanı olan izleyici tarafını önemseyerek, sanatçı ve izleyicinin nasıı bir diyalog içerisinde bulunduklarını tasarlamak gerekmektedir (Boynudelik, 2002). Kamusal açık mekânlarda gerçekleşen bir faaliyet olarak, sokak sanatçıları tarafından gerçekleştirilen, planlanmış özel ya da resmi programlar, bu alanlarda yapılan aktiviteler olmaya başlamıştır (Görsel 19). Konserlerin, resmi törenlerin ya da festivallerin düzenlendiği yerler, gün boyunca, aynı zamanda sokak sanatçılarının da performans sergiledikleri alanlar olabilmektedir (Carr ve diğ., 1992). Tarihi dokuda yapılacak bu tür etkileşimli sanat faaliyetleri insan kalabalığı, toplulukların birlikte var olma ve sanat için bir araya gelme arzularını bir arada daha güçlü sunar. Bu kapsamda izleyici etkileşimli sanat, performans sanatı yoluyla sanatçının kentlilerle temas etmesine olanak verir. İzleyici etkileşimli sanatın bir başka yolu, kamusal sanat nesnesinin kentlilerle ilişki kurmasını sağlamaktır (Görsel 20-22). Günümüzde iletişim 
teknolojilerinin gelişmesi sayesinde kentliler, kamusal mekândaki hareketleri sırasında dijital araçları sayesinde kamusal sanat etkinliğinin bir parçası olabilirler (Görsel 21).

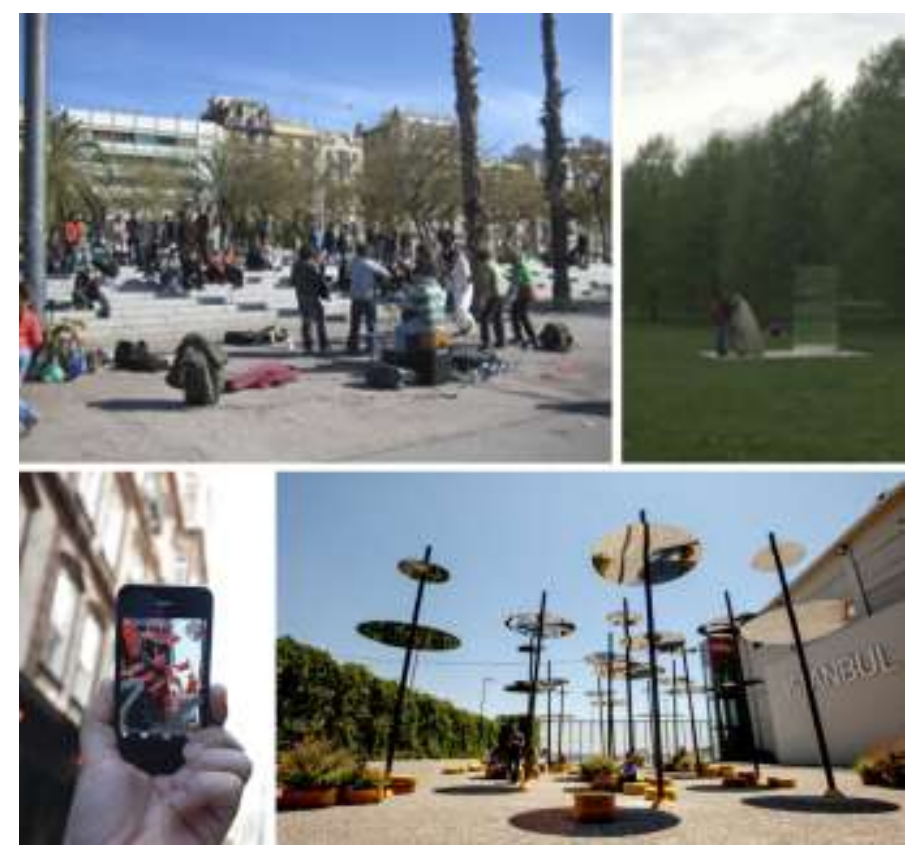

Görsel 19. Üst Solda. Barselona'da Sanat Performansı (yazar arşivi). Görsel 20. Üst Sağda. Londra Hyde Park'da İzleyici İle Etkileşimli Sanat Objesi (yazar arşivi). Görsel 21. Alt Solda. Pattu Mimarlık, Invisible İstanbul, İstanbul. Görsel 22. Alt Sağda. So? Mimarlık, Göğe Bakma Durağı, Karaköy.

Kamusal Mekânda Sanata Farklı Yaklaşımlar: Dünya sanatçılarının birbirine yaklaşması, günümüz sanat çalışmalarını küreselleşen, sosyal ve kültürel olayları farklı disiplinler aracılığıyla çözümleyen, yere bağıı olmayan tutumlara çekmeye başlamıştır. Sanat eserlerinin ve faaliyetlerinin kapalı mekânlardan, açık kentsel mekânlara geçmesi ve ortaya çıkış nedenlerinde yaşanan farklılaşmalar, sanatın insan yaşamındaki sınırlarını oldukça genişletmiştir. Günümüzde, sanatçı, mimar, plancı ve profesyonellerin işbirliğiyle gerçekleştirilen sanatsal etkinliklere bakıldığında, kamusal sanatın sosyal konulara daha çok yer verdiği ya da mimari ölçekte de uygulandığı görülmektedir. Kamusal mekânlarda yapılan, sanatçıların kendi düşüncelerini, sanat objesi yoluyla özgürce ortaya koyabilmeleri için ortam yaratan, sosyolojik, kültürel ve psikolojik katkılar sağlayan kamusal sanatta artık; tarih, çevre, mekân ve siyasetin izlerine rastlanmaktadır. Örneğin, mimari kabuğun kendisi tarihi doku ile bütünleşen bir sanat eserine dönüşebilmektedir (Görsel 23). Portekiz Fatima'da Kutsal Tören 
alanındaki heykel (Görsel 24), mekânda kendi varlığını yüceltecek bir büyüklükte iken, Miami Beach'de sokak arasındaki bağlantı köprüsü beklenen biçimin ötesinde farklılık yaratmaya çalışan bir anlayışla yapılmıştır (Görsel 25). Sosyal içerikli mimari ölçekte bir yerleştirme bazen bir kent meydanın merkezinde iken (Görsel 26), bazen boş bir parselde kendine yer bulabilmektedir (Görsel 28). Kamusal sanat objesi, zamanın etkilerine karşı açıkta bırakılarak taşıdığı anlam güçlendirilebilir (Görsel 27).
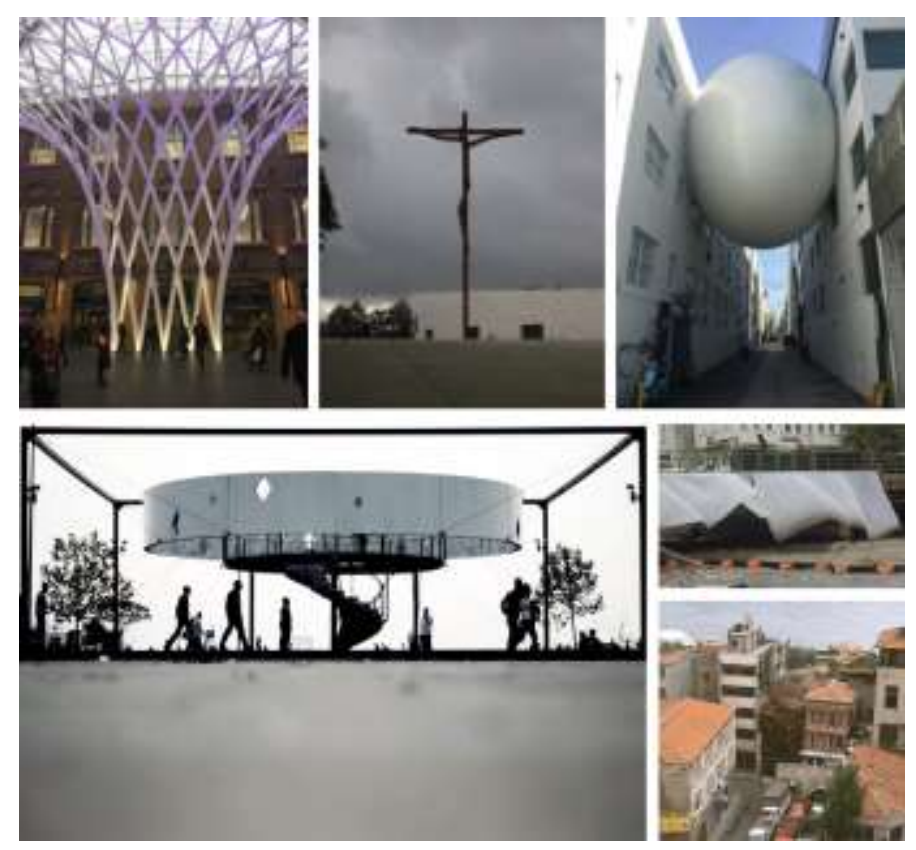

Görsel 23. Üst Solda. Londra Kingston İstasyonu’nda Mimari Ölçekte Kamusal Sanat (yazar arşivi). Görsel 24. Üst Ortada. Portekiz Fatima Kutsal Tören Alanı’nda Heykel (yazar arşivi). Görsel 25. Üst Sağda. İki Yapı Arası BağlantısıSokak Köprüsü, Miami yazar arşivi). Görsel 26. Alt Solda. Salon Architects, Panorama, Beşiktaş. Görsel 27. Alt Sağ-

Üst. Özgül Arslan, Maruz, Yoğurtçu Parkı, Kadıköy. Görsel 28. Alt Sağ-Alt. Doris Saldeco, Untitled, Karaköy.

Kamusal sanatın dünyadan ve Türkiye'den örneklerine bakıldığında çoğu eserde, sanat eserinin izleyici üzerinde bıraktığı etki, onunla kurduğu iletişim ve etkileşim, sanatçının tahmini ötesine geçebilmektedir. Bununla beraber aynı eserin birden fazla ortaya çıkış biçimi olabilir. Bazen bir yerleştirme aynı zamanda kent mobilyası olarak kentliler tarafından kullanılırken, bir yüzey yaratma çalışması, kültürel ya da tarihi bir konuda hassasiyet oluşturabilir. Bu nedenle her bir örnek; farklı bir ortaya çıkış biçiminin de taşıyıcısı olabilir. 


\section{5. Çalışma Alanı: Amasya ve Amasya'da Gerçekleştirilen Kentsel Müdahalelere Bakış}

Amasya, İris Nehri'nin açtığı vadi eteklerinde konumlanan, yüksek dağlarla sınırlanmış, tarihi günümüzden 3500 yıl öncesine dayanan (Dönmez, 2014) bir Anadolu kentidir. Farklı medeniyetlerin izleri katmanlaşarak, günümüzdeki kent dokusuna, plan düzleminde karakterini kazandırmıştır. Özellikle Amasya'nın kültürel ve mimari kimliğini oluşturan tarihi dokusunda, zaman içinde gerçekleşen bozulma ve yıpranmalar açıkça gözlemlenmektedir. Tarihi kent, Helenistik Dönem, Roma Mimarisi, Beylikler Dönemi, Selçuklu ve Osmanlı eserlerinin yanı sıra; Cumhuriyet Dönemi'nde inşa edilmiş yapıların izlerini de taşımaktadır. Son zamanlarda artan hızlı yapılaşma faaliyetlerine rağmen, kentin bugün korunabilen dokusu bile, Amasya'nın müzekent niteliğini karşılamaya yeterlidir. Amasya 1970'lerden itibaren, özellikle tarihi dokuyu koruma bilinci ile çeşitli kentsel müdahaleler geçirmiştir. Bu müdahalele biçimlerinden ilki, tarihi doku öğelerinin etrafındaki informel yapıların temizlenerek, tarihi yapıların açığa çıkarılması şeklinde olmuştur. İkinci müdahalede, tarihi dokuya sahip alanlarda onarılması gereken bakımsız yapılar belirlenerek tadilat projeleri gerçekleştirilmiştir. Bu müdahalelerin sonucunda, mevcut olanı restore etmek, envanteri bulunan ve yerinde olmayan tarihi yapıyı tekrar inşa etmek ve doku bütünlüğünü sağlamak hedeflenmiştir. Tarihi dokuda gerçekleşen üçüncü müdahale biçiminde ise, tarihi dokudaki boş parsellerde, turizme yönelik yeni yapılar inşa edilmiştir. Bu yapılar eskiyi sadece cephe karakterine bağlı kalarak kopya etmiş ve tarihi dokunun ekonomik, kültürel ve sosyal dengelerinin değişmesine neden olmuştur.

Günümüzde yeni gelişme alanlarında ve kent merkezinde yüksek katlı yapılaşma ve tarihi dokularda yapılan replika yapıların arttığı gözlenmektedir. Bununla beraber kentliler yeni yerleşim alanlarına taşınmakta, gelir grupları arasında mekânsal olarak da bir ayrışma yaşanmaya başlamaktadır. Tarihi dokuda gerçekleştirilen eskiye öykünen fakat dokuya uyumsuz yapılaşmalar ve turizm odaklı yeniden işlevlendirmeler tarihi dokunun hem sosyo-kültürel hem de mimari bütünlüğünü zedelemektedir. Tüm bunlar gelecekte yerel kimliği oluşturan kent dokusuna ait yaşam rutinlerinin yok olmasına, toplumun ayrışmasına ve müze-kent niteliğindeki Amasya'nın mimari mirasının (architectural heritage) yok olmasına neden olabilir.

$\mathrm{Bu}$ perspektiften Amasya'da yer alan kamusal sanat örneklerine bakıldığında, bu eserlerin sembolik ifadeler içerdiği gözlenmiştir (Tablo 1). Bu ifadeler, çoğunlukla heykel 
formunda sanat nesnesine dönüştürülmüştür. Mevcut çalışmaları kamusal sanatın ortaya çıkış biçimlerine göre yorumlarsak, kamusal alanda sergileme dışında diğer başlıklarda örnekleri kapsadığı görülmektedir. Yerleştirme çalışmalarına, Yalıboyu Promenadı üzerindeki tarihi figürlere ait heykelleri örnek gösterebiliriz (Tablo 1'den Görsel 1-2-3). Bunlar, kentin kültür ve tarihine ilişkin öğelerin figüratif bir şekilde yorumlandığı çalışmalar olmuştur.

Kent mobilyaları, Yalıboyu Promenadı üzerinde oldukça çeşitli formlarda ortaya çıkmaktadır. Bu mobilyalar bağımsız ve soyut sanatsal bir ifade biçimine dönüşmektense, renkli bir replika olarak asıllarını yansıtmaktadır (Tablo 1'den Görsel 4-9 arası). Yavuz Selim Meydanı merkezinde yer alan Atatürk Anıtı ya da Yalıboyu Promenadı üzerindeki Türk Bayrağı tarihi ve milli değerleri hatırlatan anıtsal bir yaklaşımı benimsemiştir (Tablo 1'den Görsel 11 ve 12). Yeşilırmak üzerinde yer alan yeni köprüler, modern malzeme ve formlarının yanısıra daha geleneksel demir işçiliği örneklerini de içerebilmektedir (Tablo 1'den Görsel 10). Amasya'da izleyici ile etkileşimli sanat konserler ya da açık hava gösterileri yoluyla gerçekleşebilmektedir. Etkileşimin bir başka örneği, Yalıboyu Promenadı üzerinde Selfie Çeken Şehzade Heykeli olarak görülebilir. Bu, heykel formunda bir yerleştirme çalışmasıdır. Fakat tarihi dokudaki konumu ve kullanıcıların hareketlerini bir yönden taklit ediyor oluşu, onun kentlilerle ilişkisini ve diyaloğunu güçlendirmektedir (Tablo 1'den Görsel 13).

Amasya'da Yalıboyu Promenadı́ndaki zemin taşları ile yüzey oluşturma çalışması ya da duvar rölyefi, duvar-zemin boyama ve yüzey oluşturma çalışmalarına örnek olarak verilebilir (Tablo 1'den Görsel 14-16). Kentin doğu çıkışında, dağ yüzeyinde yer alan Yapay Kaya Mezarları ise tarihi bir kültür varlığının bire bir replikası olarak yeni bir yüzey oluşturma çalışması olmuştur (Tablo 1'den Görsel 15).

Bunların dışında kamusal mekanda, tarihi artifaktlara öykünerek tasarlanmış, tarihi doku ile kavramsal ya da fiziksel olarak ilişki kuran ve kentlilerle temas eden kamusal sanat örnekleri bulunmamaktadır.Bir başka deyişle, Amasya'da yapılan kamusal sanat örneklerine bakıldığında çoğunun var olan durumun aynen yansıtılması olarak ortaya çıktığı görülmektedir. Tarihi artifakt, kopya eser-replika olarak sanat eserine dönüştürülmektedir. 
SDÜ ART-E

Güzel Sanatlar Fakültesi Sanat Dergisi

Aralık'19 Cilt:12 Sayı:24

ISSN 1308-2698

Tablo 1. Amasya Kenti'nde Yer Alan Kamusal Mekânda Sanat Örnekleri (yazar arşivi).

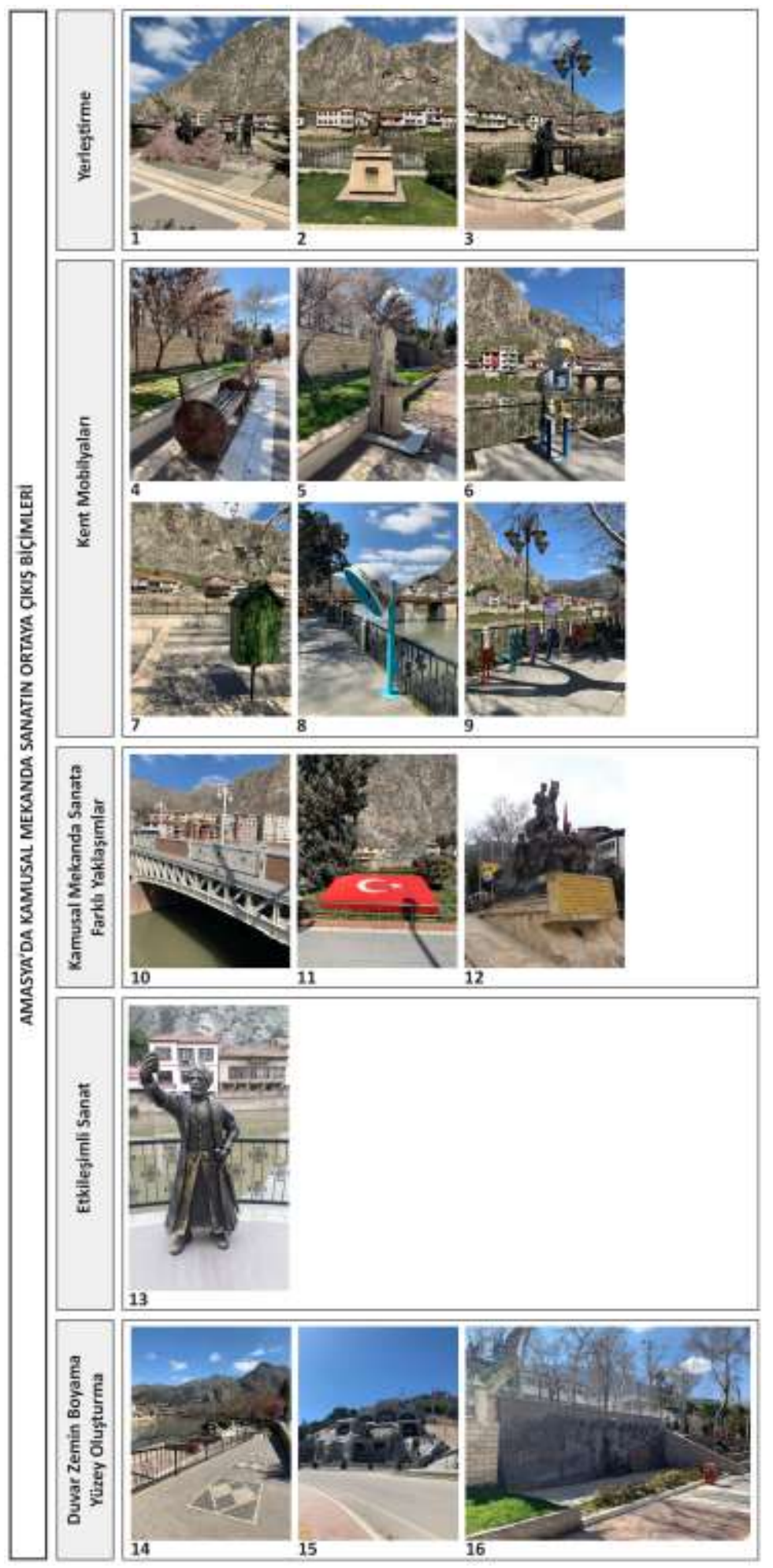




\section{Alan Çalışması}

Yukarıda tespit edilen müdahale sorunları ışığında, Amasya Üniversitesi'nde, birinci sınıf, Şehir Bölge Planlama ve Kentsel Tasarım ve Peyzaj Mimarlı̆̆ı Bölümleri'nden oluşan bir öğrenci grubunun katılımıyla, tarihi kentlerde mikro müdahalelerin nasıl olması gerektiği üzerine bir tartışma zemini yaratan "Kentsel Mekâna Müdahaleler: Özgün Mahalle Dokusunda Karşılaşma Mekânları" isimli bir çalıştay gerçekleştirilmiştir. Çalıştayda, tarihi kentlerde kimliği korumaya yönelik kentsel mikro müdahalelerde, kentliler için karşılaşma mekânlarının yaratılmasında tarihi kentin artifaktlarının nasıl sanat eserlerine dönüştürülebileceği araştırılmıştır. Çalıştayda peyzaj mimarlığı ve şehir bölge planlama öğrencilerinden oluşan 5 grup yer almıştır.

Alan çalışması için, Amasya'nın tarihi mahallelerinden iki tanesini dolaşan bir rota çizilmiştir (Görsel 29). Bu rota, nehrin ayırdığı iki vadi eteği üzerindeki tarihi mahallelerde çizgisel bir dolaşım önermektedir. Helkıs Mahallesi'nden başlayan rota, Sofular Mahallesi'nde son bulmuştur. Bu mahalleler, mimari yapıların niteliği açısından birbirine benzese de kentsel bağlam açısından birbirlerinden farklıdır. Helkıs Mahallesi, vadi eteğine lineer yerleşmiş ve yoğun kentsel dokudan tren yolu ile izole edilmiştir. Sofular Mahallesi ise vadi eteğine dik bir şekilde yerleşmiş ve kentsel manzaradan olabildiğince yararlanmaktadır. Bu mahallelerde, yerel kimliği oluşturan, nadir/ender/anormal/sıklıkla karşılaşılan artifaktların (dokunsal, işitsel, görsel vb. ) tespit edilmesi hedeflenmiştir.

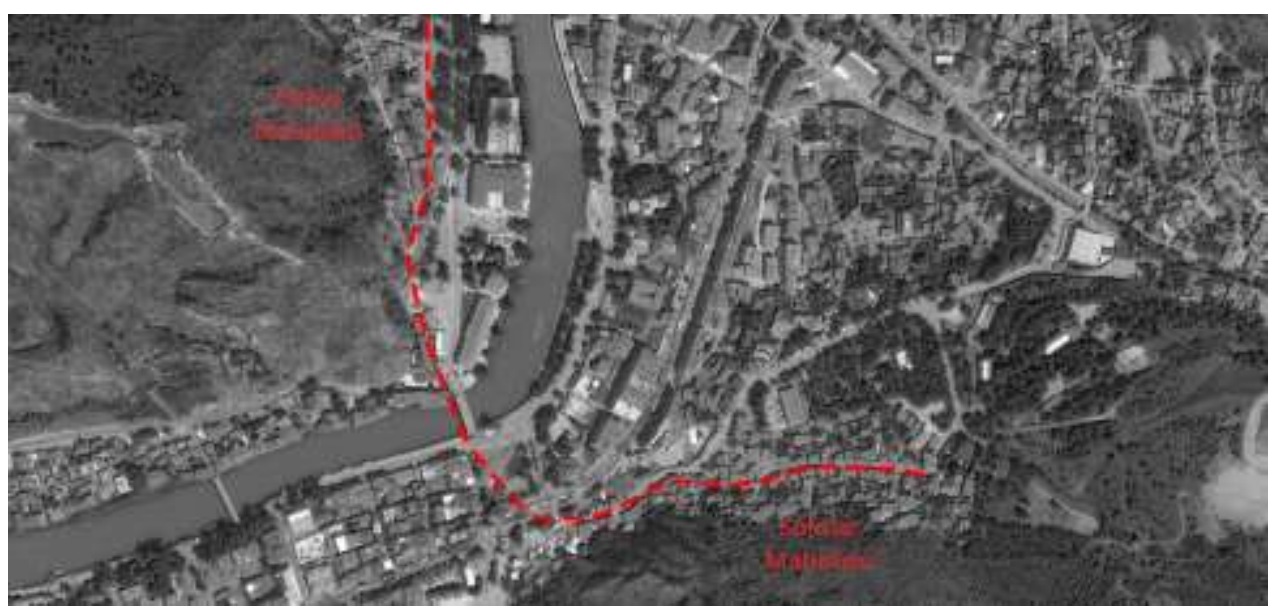

Görsel 29. Alan Çalışması//Rota: Helkıs Mahallesi ve Sofular Mahallesi (Google Earth Görseli). 
Çalışma rotası üzerindeki keşiflerde fotoğraf ve eskizlerle belgeme çalışması yapılmış, Mimarlar Odası'ndan Yüksek Mimar Hakkı Göztaş'ın rehberliğinde mahallelerin ve Amasya kenti tarihi dokusu ve yaşam kültürü hakkında bilgi verilmiştir. Alan gezisi sırasında yapılan tespitler ve tartışma ortamı öğrencilerin çevrelerine eleştirel bir gözle bakarak tarihi doku ve bağlantılı kentsel müdahaleler hakkında sorgulamalar yapmasını sağlamıştır. Kamusal sanat, mekândan elde edilen veriler üzerine kurulmuş ve sanat nesnesi ile mekânın bütünleşmesi için, aralarında nasıl bir ilişki olması gerektiği tartışılmıştır. Bu noktada kamusal sanat eserini ortaya koyacak 5 faktör belirlenmiştir. Birinci faktör, kentsel artifakt; ikincisi ise kentsel artifaktın yorumlanması sonucu ortaya çıkacak kamusal sanat eserinin konumudur. Üçüncü faktör, kamusal sanat eserinin ortaya çıkış biçimi; dördüncü ise, kamusal sanat eseri ve mekân arasında kurulan ilişkidir. Son olarak, kamusal sanat eseri ile kentliler arasında kurulan ilişki yani ortaya çıkan karşılaşma mekânlarında belirebilecek kentsel eylemler tartışılmıştır (Tablo 2). Bu anlamda o yere özgü artifaktların keşfi, yer ile bütünleşen aşağıdaki sanat nesnelerini yaratarak, karşılaşma mekânlarının tasarlanmasını sağlamıştır.

Tarihi Dokuda Kamusal Sanat Önerisi 1 // Sokak Sahnesi (Street Stage): Birinci grup, çalışmalarında tarihi kent dokusunda kapıların çevrenin atmosferini nasıl etkilediğine odaklanmıştır. Farklı renklerde, işlemelerle süslenmiş, insan ölçeğinde çeşit çeşit kapı geleneksel dokuda birbirine benzeyen mimari doku içerisinde dikkat çeken bir elemana dönüşmektedir. Fiziksel niteliklerinin yanında kapıların sosyal ve kültürel anlamları da vardır. Kapılara ait elemanlar (kol, tokmak) ve fiziksel nitelikleri (boyut, malzeme) ait oldukları yapının kullanıcıları hakkında örtülü bilgiler içeren semboller taşımaktadır. Kapı geleneksel dokuda, kamusal mekâna açılma noktasıdır. Önünde bekleyeni korur ve ona sığınak oluşturur. Özel alan ve kamusal alan arasında bir eşiktir ve sınır oluşturur. Tarihi dokudan toplanan sokak kapısı artifaktları, tek tek açıldıkları mekânları bir araya toplar ve kamusal mekân içerisinde karşılaşma mekânını tanımlar.

Bu bağlamda, "Sokak Sahnesi (Street Stage)", Helkıs Mahallesi'nde geleneksel kent dokusu ve tren yolu arasında kalan atıl alana yerleştirilmiştir. Farklı kotlarda ve birbirinin üstüne ve yanına yerleşen kapılar, hem açıldıkları mekânı tanımlayarak atıl alanda bir karşılaşma 
mekânının sınırlarını çizer, hem de tren yoluna ait istinat duvarı önünde geleneksel cephenin yeni bir yorumunu yaratır. Bu kapılar merdivenler aracılığıyla zemine bağlanır. Bu anlamda çalışma izleyicilerle bir etkileşim ve diyalog kurar. Onlara oyun fırsatı verir. Kentlileri bir mekânda birleştirir-toplar ya da kendi cephelerini bir sergi objesine dönüştürerek kendini izletir (Tablo 2).

Tarihi Dokuda Kamusal Sanat Önerisi 2 // Sokak Durağı (Street Stop): Ikinci grup, çalışmalarında tarihi kent dokusundaki Sofular Mahallesi'nde 3 yolun kesiştiği yüksek duvarlar çevrili bir odak noktasında, duvar ve kaldırımların çevrenin atmosferini nasıl etkilediğine ve kentliler tarafından nasıl kullanıldıklarına odaklanmıştır. Duvarlar yatayda ve düşeyde kentin dolaşımının niteliksel ve niceliksel özelliklerini belirler, içeri ya da geri çekilmeler yaparak kentsel nişleri oluşturur. Kaldırımlar ise bazen katlanarak merdivenlere dönüşebilir. Duvarlar, yüzeylerinde yuva yapmış kuşlarla, onlara tutunarak büyüyen sarmaşıklar ile kaldırımlar ise kenarlarında ya da duvar nişlerinde dinlenen kentliler -çocuklar, yaşlılar, kediler, köpekler- için bir durma noktası ya da hareketin izi olarak anlam kazanırlar. "Sokak Durağı (Street Stop)", oluştuğu noktada duvar ve kaldırım yüzeyleri olarak mekâna yayılır. Bazen zeminde ya da duvar yüzeyinde boyama şeklinde ize dönüşür ve hareketin izini çizer, bazen duvar nişlerine ilave nişler oluşturur ve tüm kentlilerin durma noktalarını artırır. Bu çalışmanın ortaya çıkış biçimi, duvar-zemin boyama ve yüzey oluşturma ile kent mobilyası şeklinde gerçekleştirilmiştir. Aynı zamanda bu çalışma, kamusal sanata farklı bir perspektiften bakarak -hayvanların, çocukların ve yaşılıarın da gözünden- yaratılan nesnenin sosyal bir anlam kazanmasını da sağlamıştır. Ortaya çıkan kamusal sanat nesnesi, kullanıılarına durma, dinlenme, hareket ve birbirleriyle temas etmelerini sağlayarak kentlilerle ilişki kurar ve kent içinde karşılaşma mekânlarının olasılıklarını artırır (Tablo 2).

Tarihi Dokuda Kamusal Sanat Önerisi 3 // Kent Gözlem Yeri (City Observatory): Üçüncü grup, çalışmalarında kentin merdivenlerine odaklanmıştır. Sofular Mahallesi konumundan dolayı, Amasya Kalesi, tarihi Hatuniye Mahallesi, Kent Meydanı'nı da kapsayan geniş bir görsel alana hakimdir. Mahallede birçok merdiven farklı kotlardaki yapıları ve alanları birbirine bağlamaktadır. Bu merdivenlerden ulaşılan yüzeylerden farklı perspektiflerde kenti izlemek mümkün olmaktadır. Bu nedenle; Sofular Mahallesi'nde tarihi merdiven artifaktları ve 
ulaştıkları yüzeyler kenti gözlemleme noktalarına dönüşmektedir. "Kent Gözlem Yeri (City Observatory)", kenti gözleme eylemini tarihi dokunun üstüne taşıyarak gerçekleştirmektedir. Kamusal sanat nesnesi merdivenlerin kullanımıyla kent mobilyasına dönüşürken, aynı zamanda sanat nesnesinin kentsel mirası farklı perspektifleriyle görünür kılması sağlanmıştır. Kentliler kamusal sanat nesnesinin yüzeyleri ve merdivenleri arasında hareket edebilir ve yüzeylere oturup kenti seyredebilirler (Tablo 2).

Tarihi Dokuda Kamusal Sanat Önerisi 4 // Kentsel Evren (Urban Cosmos): Dördüncü grup, çalışmalarında tarihi kentin çatılarına odaklanmıştır. Bir kent, içinde yaşayayanlar ve onunla ilişki kuranlar açısından onların evrenidir. Bu evren içinde yer edindikleri yer ise evleridir. Uzaydan bakıldığında çatılar kentlilerin yaşam varlıklarını temsil eder. Bu çalışmada kamusal sanat, tarihi çatı artifaktlarının kent evreninin ayrılmaz parçası ve yaşamın simgesi olduğu kabulü üzerinden, yeryüzündeki temsil biçimlerine dönüşmüştür. "Kentsel Evren (Urban Cosmos)", Helkıs Mahallesi'nde, tarihi dokuya bir geçit olarak yerleştirilmiş ve kentlilerin farklı bir gözle yaratılan bu yeni mikro evreni deneyimlemesi amaçlanmıştır. Bu geçit kentlileri harekete teşvik eder ve yaratılan simgesel ögelerle kentliler etkileşime girer (Tablo 2).

Tarihi Dokuda Kamusal Sanat Önerisi 5 // Kentsel Vaha- Çoğalma(Urban OasisMitosis): Beşinci grup, çalışmalarında kentin anıt ağaçlarına ve yeşil dokusuna odaklanmıştır. Amasya tarihi kent dokusunun önemli bir parçası olan anıt ağaçlar ve yeşil doku, taş duvarlar, kiremit çatılar ve arnavut kaldırımlı sokaklar arasında yerleşen tarihi kentin renkli artifaktlarıdır. Yeşil doku tarihi yapıların taş/ahşap strüktürü arasında bir vaha (oasis) gibi belirip ağlar örerek ve çoğalarak (mitosis), yapıların strüktürlerini birbirine bağlar. "Kentsel Vaha-Çoğalma (Urban Oasis-Mitosis)" tarihi dokunun renkli sanat objesi olarak Sofular Mahallesi'nin kente bakan sokaklarında, yapıların arasında yer bularak oluşturduğu karşılaşma mekânına kentlileri çeker. Kamusal sanat mekânı örerek, kamusal alan sergisine dönüşür. İzleyicilere altında hareket ve kendisine bakış imkânı tanır (Tablo 2). 
SDÜ ART-E

Güzel Sanatlar Fakültesi Sanat Dergisi

Aralık'19 Cilt:12 Sayı:24

ISSN 1308-2698

Tablo 2. Tarihi Kentsel Mekâna Kamusal Sanat Yoluyla Mikro Müdahaleler: Karşılaşma Mekânları.

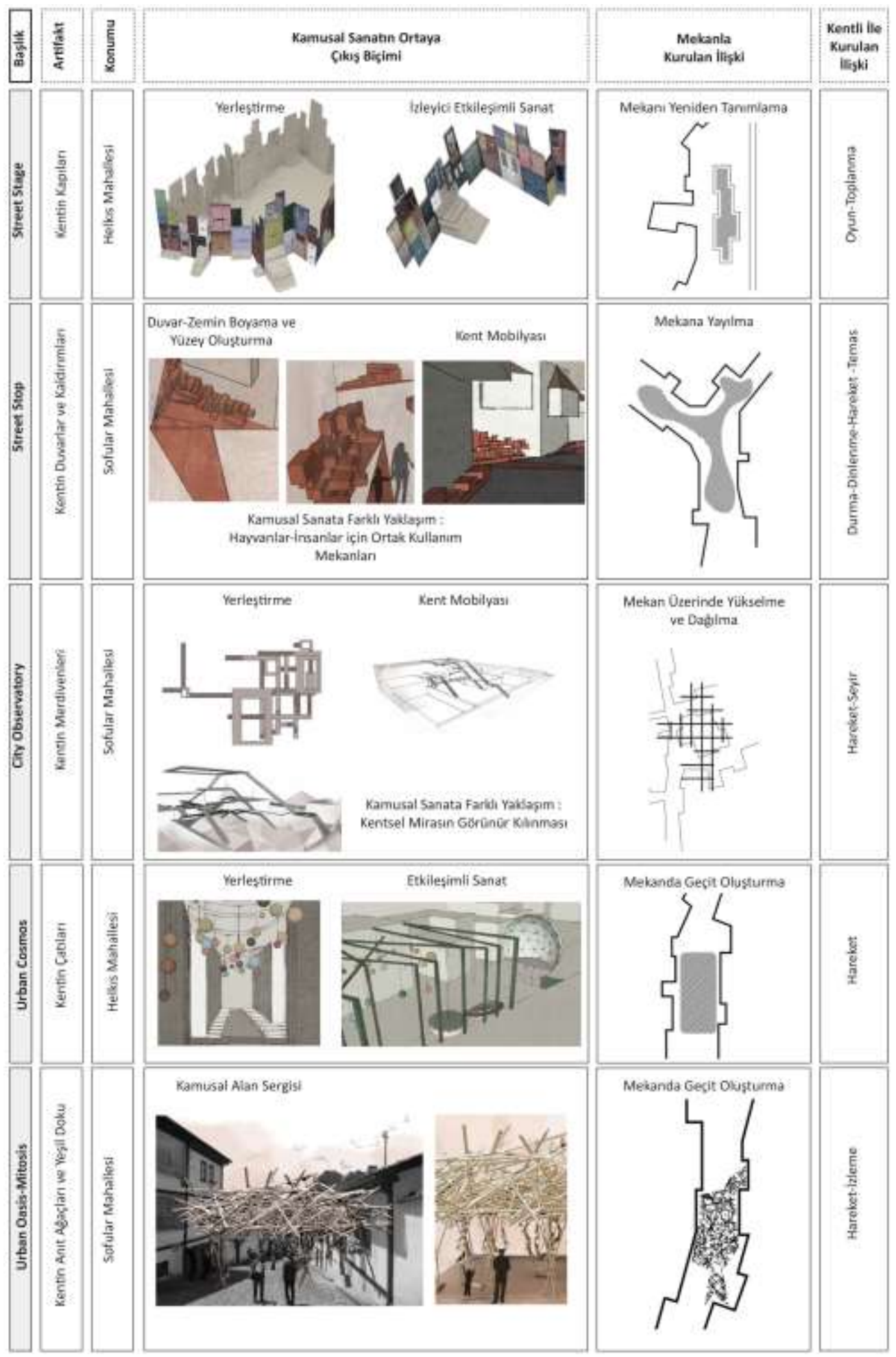




\section{Tartışma ve Sonuç}

Bu makalede öncelikle, kentsel mekâna müdahale kavramı ele alınarak; makro ve mikro müdahale biçimleri değerlendirilmiştir. Daha sonra kamusal sanat, tarihi kentlerde gerçekleşecek mikro bir müdahale biçimi olarak ortaya konulmuş ve kamusal mekânda ortaya çıkış biçimlerine göre gruplandırılmıştır. Her bir biçim, kamusal mekânda yer alışı ve kentliler ile kurduğu ilişki açısından birbirinden farklılık gösterebilmektedir. Fakat tüm farklı var oluş biçimlerinin ortak noktası, kamusal mekan içerisinde yarattıkları karşılaşma ve diyalog mekanlarının yanı sıra, tarihi kentte, kentsel kimliği ve kent imajını güçlendirmek adına bir araç olmalarıdır.

Dünyadan ve Türkiye'den başarılı örneklere bakıldığında, Amasya'da kamusal sanat eserlerinin, tarihi artifatkların aynen kopyalanması olarak değil, sanatsal bir bakış açısı ile yorumlanması gerektiği sonucuna varılmıştır. Böylece kamusal sanatın, kentli ve kent ile kurduğu ilişki güçlenecek ve sanat, kentsel kimliğin korunması amacıyla kentte gerçekleştirilen mikro bir müdahaleye dönüşecektir. Bu makalede sonuçları incelenen çalıştay ürünleri, kamusal sanatı, tarihi dokuya kentsel mikro müdahale biçimi olarak kabul ederek, tarihi morfolojiye göndermeler yapmış ve tarihsel dokuya ait artifaktları sanat eseri olarak yorumlamaya çalışmıştır. Mikro müdahaleler, kamusal mekânın yeniden üretimi olarak değil, kentsel kimliği oluşturan parçaların bulunması, güncel ihtiyaç ve kullanımlarla değerlendirilmesi şeklinde gerçekleşmiştir.

Daha önce de bahsedildiği gibi, kamusal sanatın ortaya çıkışında birçok yol vardır. Önemli olan bu süreçte, önce tarihi dokunun karmaşık örgütlü yapısını çözümleyerek, kentsel bütünü oluşturan parçaları özümsemektir. Bu özümseme, kamusal sanat eserinin ortaya çıkış sürecinde yerleştirileceği konumu belirlediği gibi; kamusal mekân ve kentliler arasında kurulan ilişkiyi de tanımlayacaktır. Örneğin, Sofular Mahallesi'nde, duvarlardan taşan yeşil doku ve duvarları birbirine bağlayan sarmaşıklar, yine aynı mahallede, bir geçit olarak kamusal mekânda, sanat eseri olarak yorumlanmıştır (Kentsel Vaha-Çoğalma/Urban Oasis-Mitosis). Sokak Durağı/Street Stop çalışmasında ise, Sofular Mahallesi'nin meydanında gözlemlenen, duvarlarda-merdivenlerde dinlenen, sokak hayvanları ve insanlardan esinlenilerek, duvarlar ve merdivenler, sokağın durak noktaları olarak yorumlanmış ve aynı noktada kamusal sanat eseri 
olarak meydanın farklı noktalarına dağıtılmıştır. Bu şekilde kentliler, bu noktalarda duraklayabilecek ve diyaloğa geçmeleri sağlanabilecektir. Kamusal sanat ve tarihi artifaktın nasıl yorumlandığı ve kamusal sanat eserinin mekân ile kurduğu ilişki, mikro müdahalenin de ortaya çıkaracağı değişimleri etkilemektedir.

Sonuç olarak, tarihi kentler, kamusal sanat yoluyla gerçekleştirilen mikro müdahaleler sayesinde kimliğini ve var olan kentsel dokusunu koruyabilir. Çalışma sonunda ortaya çıkan kamusal sanat eserleri ve kentle-kentli ile kurduğu ilişkiler üzerinden bakılırsa; kamusal sanat ile yaratılan karşılaşma mekânları, tarihi kent içinde mikro müdahalelere dönüşerek; toplumsal ilişkileri güçlendirebilir ve kentsel hareketliliği sağlayarak çeşitli konularda farkındalık yaratabilir. Bu şekilde, tarihi kentte, kültürel ve sosyal gelişimin hızlanabileceği, kentsel kimliğin kolektif bellekte güçlenerek kimliğin korunmasına yönelik çalışmaların bu şekilde güçlendirilebileceği sonuçlarına varılmıştır. Bu çalışmaların faydası makro ölçekli müdahalelere bile yansıyabilir. Toplumsal bilincin ve kentsel mekân bilincinin artması, kentlilerin yaşadıkları kent için fikirlerini ve görüşlerini ifade etmelerini teşvik edebilir ve bu şekilde katılımcı makro müdahalelerin önü açılabilir (Mccarty, 2006).

Son olarak, kamusal sanat, bu makalenin sonuç ürünleri üzerinden tartışıldığı gibi, kent kimliğini ve imajını güçlendiren, ekonomik ve kolay uygulanabilen, aynı zamanda etkisi kent ölçeğinde, toplumsal yaşantıda dahi hissedilebilecek bir müdahale türü yarattığı için; kamu kurum ve kuruluşlarının kamusal sanat üretimine, hem mekân hem de fon sağlaması ve kamu kurumlarınca kamusal sanat üretiminin desteklenmesi gerekmektedir (Hein, 1996).

Amasya özelinde bakııırsa; 2007-2011 yılları için hazırlanan Amasya ili Stratejik Planı́nın vizyonu kentin tarihi ve kültürel kimliğinin korunarak gelecek nesillere aktarılmasını sağlamak olarak belirlenmiştir. Bu vizyon kapsamında 3 ana hedef ortaya konulmaktadır. Bu hedeflerden birincisi, kültür varlıklarının korunmasını ve sağlıklaştırılmasını sağlamaktır. İkincisi, kültür varlıklarını koruma konusunda çalışabilecek ya da dönüşümleri sürecinde onları işleterek değerlendirebilecek kişileri eğitmektir. Üçüncü hedef ise, kentin kültürel ve tarihi birikiminin turizm faaliyetleri kapsamında değerlendirilerek daha çok ziyaretçinin kente ulaşmasını sağlamaktır (Mortan ve Arolat, 2014). Bu stratejik hedeflerin gerçekleşmesinde, hem Amasya hem de Amasya gibi diğer tarihi kentlerde, kentin kendi tarihi ve kimliğinden beslenen kamusal 
sanatın etkili bir araç olabileceği düşünülmektedir. Kamusal mekânda sanat, bu anlamda tarihi kentlerde gerçekleştirilecek mikro müdahaleler olarak, tarihi mirasın taşıyıcısı olacaktır.

\section{Kaynakça}

Akgün Yüksekli, B. (2015). “Mikro Müdahale: Kentsel Problemlere Mimarlık Ölçeğinden Yanıtlar", Balıkesir Kent Sempozyumu 2015 Bildiriler Kitabı, ed. Şener Ceryan, Abdullah Soykan, Balıkesir: Balıkesir Büyükşehir Belediyesi Kent Arşivi Yayınları, No:11, s.321-331.

Bayram, B. (2007). Kamusal Mekân Kalitesinin Yükseltilmesinde Yöntemler ve Kamusal Sanatın Rolü, Yayınlanmamış Yüksek lisans Tezi, İstanbul Teknik Üniversitesi, FBE.

Boynudelik, Z. (2002). "Sokaklarda Sanat", SANART 5. Uluslararası Sempozyum ve Sanat Etkinlikleri Bildiri Önerisi, 1-3 Mayıs.

Carr, S., Francis, M., Rivling, L. G. ve Stone, A. M., (1992). Public Spaces, Cambridge: Cambridge Univ. Press.

Dönmez, Ş. (2014). "Amaseia Antik Kenti”, Yar Ile Gezdiğim Dağlar: Amasya, haz. Özden, F., Ankara: Yapı Kredi Yayınları, s.9-29.

Eren, Ş. G. (2007). Impacts of Privatization on Urban Planning: The Turkish Case (Ankara), METU Department of City and Regional Planning, Unpublished Ph.D. Dissertation, July, Ankara.

Eren, Ş. G. (2009). Ankara'da bir Kamu Arazisinin Özelleştirilmesi Değişen Kentsel Mekânın (Yeniden) Üretim Süreci ve Kentsel Kimlik, Mimarlar Odası Bülteni.

ERSOY, M. (2007). "Kentsel Planlama Kuramlarına Eleştirel Bakışlar", Kentsel Planlama Kuramları, Ed. M. Ersoy, 279-306. Ankara: IMGE Kitapevi.

Erzen, J. (2015). Üç Habitus - Yeryüzü, Kent, Yapı, İstanbul: YKY Yayınları.

Gökgür, P. (2008). Kentsel Mekânda Kamusal Alanın Yeri, İstanbul: Bağlam Yayıncılık.

Habermas, J. (1997). Kamusallığın Yapısal Dönüşümü, çev. Sancar, M., Bora, T., İstanbul: İletişim Yayıncilık,

Hein, H. (1996). "What Is Public Art? Time, Place and Meaning", The Journal of Aesthetics and Art Criticism, Vol 54, No 1 Winter, Wiley, s.1-7.

Jacobs, J. (2011). Büyük Amerikan Şehirlerinin Ölümü ve Yaşamı, İstanbul: Metis Yayınları. 
Keskinok, Ç. H. (2012). “Kentlerde Kamusal Mekânların Üretilmesi Sorunu: Bağlamını Yitiren Kentler”, Mimarlık Dergisi, (364).

Keskinok, H. Ç. (1998). "Kentsel Mekânın Üretilmesinde Raslantısallık Sorunu Üzerine," ODTÜ Mimarlık Fakültesi Dergisi, 18 (1-2): 91-102.

Mccarthy, J. (2006). "Regeneration of Cultural Quarters: Public Art For Place Image of Place Identity?", Journal of Urban Design, 11:2, Routledge, s.243-262.

Mitchell, W. (1992). Utopia and Critique in Art and Public Sphere, Chicago: The University of Chicago Press.

Mortan, K. Arolat, O.S. (2014). "Amasya'ya Sosyo-Kültürel Bir Bakış", Yar ile Gezdiğim Dağlar:Amasya, (haz.) Özden, F., İstanbul: Yapı Kredi Yayınları, s.349-361.

Oktay, D. (2003). "Kamusal Mekânda Sanata Güncel Bir Bakış", Yapı Mimarlık Kültür Sanat Dergisi, 264, s.105-109.

Ögel, S. (1997). Çevresel Sanat, İstanbul: iTü Mimarlık-Mühendislik Fakültesi Yayınları.

Özbek, M, (2004). Kamusal Alan, İstanbul: Hil Yayın.

Özer, B. (1986). Kültür, Sanat, Mimarlık, İstanbul: MSGSÜ Yayınları.

Remesar, A., (2001). "Public Art: Towards a theoretical framework Urban Regeneration a Challenge for Public Art", (haz.) Remesar, A., Publications de la Universitat de Barcelona.

Sheikh, S. (2007). "Kamusal Alanın Yerine Ne mi? Ya da, Parçalardan Oluşan Dünya", Olasılıklar, Duruşlar, Müzakere, Güncel Sanatta Kamusal Alan Tartışmaları, haz. Tan, P. Boynik, S., İstanbul: Bilgi Üniversitesi Yayınları, s.23-29.

Shiner, L., (2004). Sanatın İcadı: Bir Kültür Tarihi, çev. İsmail Türkmen, İstanbul: Ayrıntı Yayınları.

Şenliyer, N., (1995). "Yaya Mekânlarında Sanat Objelerinin Çevre Yasam Kalitesine Etkisi: Paris'ten bir MiA Örneği", Mimari ve Kentsel Çevrede Kalite Arayışları Sempozyumu, 5-6-7 Haziran, İstanbul: iтÜ Yayınları, s.133-139.

Tan, P.(2009). "Mikro Ölçekte Kentsel Mekân: Mimarinin Ötesine Geçmek", Arredamento, Şubat 2009, s.59-60.

Tan, P. Boynik, S. (2007). Olasılıklar, Duruşlar, Müzakere, Güncel Sanatta Kamusal Alan Tartışmaları, İstanbul: İstanbul Bilgi Üniversitesi Yayınları.

Tanaç Zeren, M. (2010). Tarihi Çevrede Yeni Ek ve Yeni Yapı Olgusu, , İstanbul: Yalın Yayıncılık. 
Tanyeli, U. (2006). "Kamusal Alanda Heykel”, Heykel Sempozyumu, İstanbul Modern, Nisan 25, İstanbul.

Uzer, E. (2013). “Kentsel Akupunktur: Bireysel Taktiklerden Kentsel Stratejilere, Küçük Ölçekli Müdahale", Mimarlık Dergisi (371).

\section{Görsel Kaynaklar}

Görsel 1-2-3-6-7-10-11-15-16-19-20-23-24-25 ve Tablo 1 içerisindeki tüm görseller Doç. Dr. Emel Birer Arşivi'ne aittir.

Görsel 4. Alt Solda. GAD Architecture, Serra Gate, İstanbul, Taksim Meydanı, https://www.gadarchitecture.com/tr/serra-gate, Erişim tarihi: 30.03.2019.

Görsel 5. Alt Sağda. So? Mimarlık, Mediterranean Triangle, Antalya, https://www.soistanbul.com/mediterranean-triangle, Erişim tarihi: 30.03.2019.

Görsel 8. Üst Sağda. So? Mimarlık, Pray For Rain, Karaköy, https://www.soistanbul.com/pray-for-rain, Erişim tarihi: 30.03.2019.

Görsel 9. Alt Solda. Salon Architects, Augmented Structures V1.1, İstiklal Caddesi, İstanbul, https://salonarchitects.com/projects/augmented-structures-v1-1/, Erişim tarihi: 30.03.2019.

Görsel 12. Üst Sağda. Paul Cocksedge Studio, Palette, İstanbul, http://www.paulcocksedgestudio.com/project\#/palette/, Erişim tarihi: 30.03.2019.

Görsel 13. Alt Solda. Muralist Örneği, Yel değirmeni, Kadıköy, http://m-city.org/2014_walls/, Erişim tarihi: 30.03.2019.

Görsel 14. Alt Sağda. Eda Soylu, Duvar Kağıdı, Balat, https://www.edasoylu.com/blank-1, Erişim tarihi: 30.03.2019.

Görsel 17. Alt Solda. So? Mimarlık, Sky Garden, Beşiktaş, https://www.soistanbul.com/sky-garden, Erişim tarihi: 30.03.2019.

Görsel 18. Alt Sağda. Pattu Mimarlık, Katı Olan Her Şey, Karakö, http://www.pattu.net/katiolanhersey/, Erişim tarihi: 30.03.2019.

Görsel 21. Alt Solda. Pattu Mimarlık, Invisible Istanbul İstanbul, http://www.pattu.net/invisible-istanbul-2/, Erişim tarihi: 30.03.2019.

Görsel 22. Alt Sağda. So? Mimarlık, Göğe Bakma Durağı, Karaköy, https://www.soistanbul.com/sky-spotting-stop, Erişim tarihi: 30.03.2019. 
Görsel 26. Alt Solda. Salon Architects, Panorama, Beşiktaş,

http://salonarchitects.com/projects/panorama/, Erişim tarihi: 30.03.2019.

Görsel 27. Alt Sağ-Üst. Özgül Arslan, Exposure-Maruz, Yoğurtçu Parkı, Kadıköy, http://ozgularslan.com/exposure-maruz/, Erişim tarihi: 30.03.2019.

Görsel 27. Alt Sağ-Alt. Doris Saldeco, Untitled, Karaköy, http://www.sanatblog.com/doris-salcedo-hafiza-duraklari/, Erişim tarihi: 30.03.2019.

\section{Teşekkür}

Amasya Mimarlar Odası kurucu üyesi Yüksek Mimar i. Hakkı Göztaş'ı saygıyla anıyoruz. 